УДК 681.513 .8

\title{
COMPLEXATION OF CONTROL THEORY METHODS IN AUTOMATION SYSTEMS FOR TECHNOLOGICAL PLANTS. PART 2. EXAMPLES
}

\author{
A. Ladaniuk, N. Lutska, V. Kyshenko, Ia. Smitiukh, D. Shumyhai \\ National University of Food Technologies
}

\begin{tabular}{|c|c|}
\hline Key words: & ABSTRACT \\
\hline $\begin{array}{l}\text { Complexation } \\
\text { Robustness } \\
\text { Coordination } \\
\text { Uncertainty } \\
\text { Emergent properties }\end{array}$ & \multirow{3}{*}{$\begin{array}{l}\text { The paper gives the examples of synthesis of existing } \\
\text { methods and principles of control to get new, more sophis- } \\
\text { ticated systems that have emergent properties and increase } \\
\text { the efficiency of complex technological systems. Authors } \\
\text { proposed combination of robust and predictive controllers, } \\
\text { fuzzy and neural systems, situational control and coordina- } \\
\text { tion, synergy and analytical methods. New control systems } \\
\text { because of their new properties, that can not be obtained by } \\
\text { trivial use both methods chosen for complexation, provide } \\
\text { qualitative and efficient control of complex plants for which } \\
\text { the standard control system can not guarantee the required } \\
\text { accuracy. }\end{array}$} \\
\hline $\begin{array}{l}\quad \text { Article history: } \\
\text { Received 01.11.2017 } \\
\text { Received in revised form } \\
28.11 .2017 \\
\text { Accepted } 15.12 .2017\end{array}$ & \\
\hline $\begin{array}{l}\text { Corresponding author: } \\
\text { A. Ladaniuk } \\
\text { E-mail: } \\
\text { npnuht@ukr.net }\end{array}$ & \\
\hline
\end{tabular}

DOI: $10.24263 / 2225-2924-2017-23-6-3$

\section{КОМПЛЕКСУВАННЯ МЕТОДВВ ТЕОРІЇ КЕРУВАННЯ В СИСТЕМАХ АВТОМАТИЗАЦÏ̈ ТЕХНОЛОГІЧНИХ ОБ’ЄКТІВ. ЧАСТИНА 2. ПРИКЛАДИ}

\section{А.П. Ладанюк, Н.М. Луцька, В.Д. Кишенько, Я.В. Смітюх, Д.А. Шумигай Національний університет харчових технологій}

У статті розглядаються приклади комплексного використання існуючих методів і принципів керування для отримання нових, більш досконалих систем, які мають властивості емерджентності та дають змогу збільшити ефективність функціонування складних технологічних комплексів. Наводяться приклади комплексування робастного та предиктивного регуляторів, нечітких і нейромережевих систем, ситуаційного та координаційного керування, аналітичних $і$ синергетичних методів. Новостворені системи керування завдяки своїм новим властивостям, які неможливо отримати при тривіальному використанні обох методів, обраних для комплексування, забезпечують якісне й ефективне керування складних об'єктів, для яких стандартні системи керування не можуть гарантувати необхідної точності за умови енегро- та ресурсоефективності. 
Ключові слова: технологічні об'єкти, методи керування, комплексування мemodis.

Постановка проблеми. Технологічні об'єкти, в тому числі харчових виробництв, мають усі характерні ознаки складних організаційно-технологічних систем. Вони являють собою сукупність різних підсистем, зв'язаних між собою процесами інтенсивної взаємодії та обміну енергією, речовиною та інформацією. Такі підсистеми є нелінійними, нестаціонарними, багатомірними та складнозв'язаними, в них тривають характерні перехідні процеси та виникають критичні й хаотичні режими. Проблема керування такими складними технологічними системами $є$ надзвичайно актуальною з точки зору підвищення ефективності їх функціонування. Однак технологічний об'єкт не можна розглядати однобічно, надаючи перевагу якійсь одній характеристиці, виключаючи іншу, наприклад, лише нелінійність або лише нестаціонарність. Тому логічним шляхом вдосконалення таких систем $є$ комплексування методів теорії керування, що поєднує різні методики досягнень сучасної теорії й практики автоматизованого керування та передових комп'ютерних технологій.

Загальна характеристика методів сучасної теорії керування, які при комплексуванні можуть приводити до суттєвого покращення процесу функціонування технологічних комплексів щодо ресурсо- і енергоефективності й точності регулювання, розглянуто в першій частині статті [1].

Мета дослідження: навести приклади моделювання систем керування, що використовують два або більше різнотипних методів синтезу для технологічних об'єктів, та оцінити ефект емерджентності щодо їх властивостей (стійкість, якість).

\section{Викладення основних результатів дослідження:}

1. Робастні системи керування для систем із запізнюванням

Розглянемо покращення якості перехідних процесів при введенні робастного регулятора в структуру системи з предиктивним пропорційно-інтегральним регулятором (ППІ-регулятор). Як відомо [2], система з ППІ-регулятором компенсує запізнювання за каналом керування (рис. 1), покращуючи перехідні процеси в системі, але якщо запізнювання в моделі $\left(\tau_{0}\right)$ та об'єкті $(\tau)$ не збігається, то перехідні процеси суттєво погіршуються. Крім того, така система виконує лише стеження за завданням $(r(t))$ та погано придушує зовнішні збурення $(d(t))$.

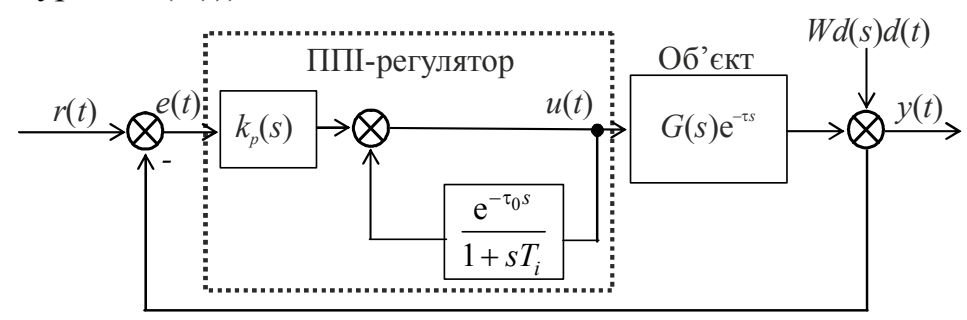

Рис. 1. Структура системи з ППІ-регулятором

Синтезуємо налаштування $k_{p}$ та $T_{\mathrm{i}}$ ППІ-регулятора, використовуючи теорію чутливості. Запишемо функцію чутливості та додаткової чутливості: 


$$
\begin{gathered}
S(s)=\left[1+G(s) \mathrm{e}^{-\tau s} K(s)\right]^{-1}, \\
T(s)=G(s) \mathrm{e}^{-\tau s} K(s)\left[1+G(s) \mathrm{e}^{-\tau s} K(s)\right]^{-1} W_{d}(s),
\end{gathered}
$$

де $W_{d}(s)$ - вагова передатна функція, що обмежує частотний діапазон дії зовнішніх збурень і

$$
K(s)=k_{p}\left[1-\frac{\mathrm{e}^{-\tau_{0} s}}{1+s T_{i}}\right]^{-1}=\frac{k_{p}\left(1+s T_{i}\right)}{1+s T_{i}-\mathrm{e}^{-\tau_{0} s}} .
$$

Тоді можна розглянути оптимізаційну задачу знаходження параметрів ППІ-регулятора за критерієм змішаної чутливості:

$$
\min _{k_{p}, T_{i}}\left\|\begin{array}{c}
W_{1}(s) S(s) \\
T(s)
\end{array}\right\|_{\infty},
$$

де $W_{1}(s)$ - вагова передатна функція, за допомогою якої налаштовується якість перехідних процесів. Мінімізація першої складової (3) визначає якісну міру відслідковування сигналу завдання $r(t)$, що залежить як від самого сигналу $r(t)$, так і від вимірювання помилки стеження $e(t)$, а також мінімізує зміну замкненої системи до малих параметричних збурень об'єкта. Друга складова (3) визначає міру стійкості зворотного зв'язку в контексті мультиплікативно збуреного об'єкта, а також стабілізацію системи відносно зовнішніх впливів. Отже, робастний ППІ-регулятор врахує область невизначеності об'єкта та регулятора, що викликані змінами параметрів об'єкта (корені характеристичного полінома й запізнювання передатної функції $G(s)$ та запізнювання в регуляторі $K(s))$. Задачу $(1-3)$ можна розв'язати методами негладкого синтезу [3].

Розглянемо результати моделювання робастного ППІ-регулятора для регулювання концентрації сиропу випарної установки цукрового заводу. Математичну модель об'єкта в номінальному режимі за каналом концентрація сиропу після п'ятого корпусу $b_{5}$ - витрата соку на перший корпус $S_{0}$ апроксимується передатною функцією:

$$
G_{0}(s)=-\frac{7.5}{3794 s+1} \mathrm{e}^{-1200 s},\left[\frac{\kappa \Gamma / \mathrm{M}^{3}}{\kappa \Gamma / \mathrm{c}}\right],
$$

де невизначеності обумовлені зміною коефіцієнта передачі, постійної часу та запізнювання в межах [7,2..7,7], [3550...3890], [1200...1600] відповідно. На практиці, як правило, при дослідженні системи 3 параметричними невизначеностями переходять до мультиплікативних невизначеностей виду, враховуючи таким чином ще й невизначеності в регуляторі.

На рис. 2 і 3 наведені перехідні процеси відносно завдання та збурення при номінальних (стовбець Nom) і найгірших комбінаціях невизначеностей (стовбець $W C$ ), а в табл. 1 - порівняльні характеристики систем різними регуляторами. Як бачимо, робастний ППІ-регулятор має найкращу якість перехідних процесів при найгірших комбінаціях невизначеностей i трохи 
гірші показники при номінальному режимі, крім того, ресурс у цієї ж системи найменший.

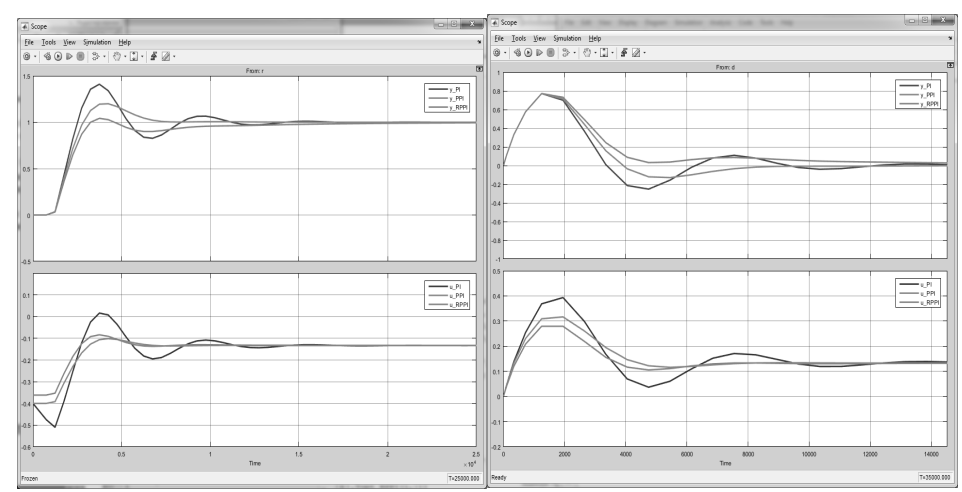

a)

б)

Рис. 2. Перехідні процеси відносно зміни завдання (а) та збурення при (б) номінальних невизначеностях

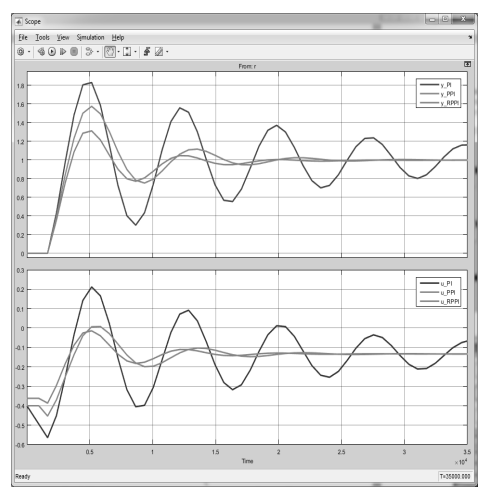

a)

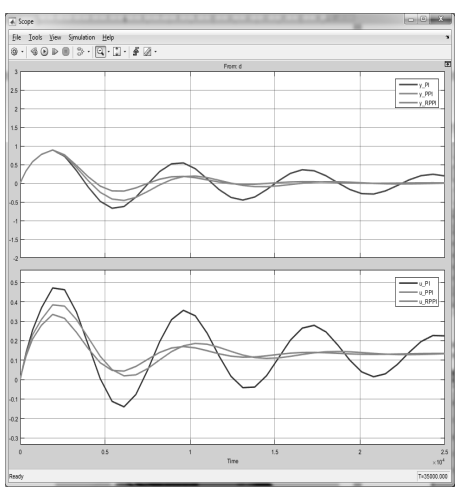

б)

Рис. 3. Перехідні процеси відносно зміни завдання (а) та збурення (б) при найгірших комбінаціях невизначеностей

Таблиия 1. Порівняльні характеристики систем з різними регуляторами

\begin{tabular}{|c|c|c|c|c|c|c|}
\hline \multirow[t]{2}{*}{ Регулятор } & \multicolumn{2}{|c|}{$\begin{array}{c}\text { Динамічна похибка, } \\
\kappa \Gamma / \mathrm{m}^{3}\end{array}$} & \multicolumn{2}{|c|}{$\begin{array}{c}\text { Ступінь } \\
\text { затухання }\end{array}$} & \multicolumn{2}{|c|}{$\begin{array}{c}\text { Час перехідного } \\
\text { процесу, с }\end{array}$} \\
\hline & Nom & $W C$ & Nom & $W C$ & Nom & $W C$ \\
\hline \multicolumn{7}{|c|}{ Перехідні процеси відносно зміни завдання } \\
\hline ПI (PI) & 0,41 & 0,82 & 0,85 & 0,33 & 16500 & $>3500$ \\
\hline ППІ (PPI) & 0,20 & 0,57 & 1,00 & 0,80 & 7500 & 2500 \\
\hline $\begin{array}{l}\text { Робастний ППІ } \\
\text { (RPPI) }\end{array}$ & 0,1 & 0,31 & 0,98 & 0,85 & 1650 & 2000 \\
\hline \multicolumn{7}{|c|}{ Перехідні процеси відносно збурення } \\
\hline ПII (PI) & 0,77 & 0,87 & 0,86 & 0,37 & 2000 & $>3500$ \\
\hline ППІ (PPI) & 0,77 & 0,87 & 1,00 & 0,78 & 1000 & 2200 \\
\hline $\begin{array}{l}\text { Робастний ППІ } \\
\text { (RPPI) }\end{array}$ & 0,77 & 0,87 & 0,96 & 0,73 & 1500 & 1550 \\
\hline
\end{tabular}


Отже, комплексування робастного та предиктивного регулятора в умовах суттєвої зміни параметрів об'єкта, в тому числі і запізнювання, є логічним вдосконаленням якості та стійкості системи 3 невизначеностями. Моделювання робастного ППІ-регулятора показало гарні характеристики перехідних процесів як при номінальних, так і при суттєвих невизначеностях.

2. Комплексування нечітких і нейромережевих систем керування

Іншим підходом до комплексування $\epsilon$ використання двох або більше інтелектуальних методів керування [4; 5]. Розглянемо ідентифікацію витрати спирту $D$ з ректифікаційної колони (РК) від витрати бражки $F_{b r}$, температури бражки $Q_{b r}$ та витрати пари на бражну колону (БК) $V_{l}$ :

$$
D=f\left(F_{b r}, Q_{b r}, V_{1}\right)
$$

На основі статистичних вибірок експериментальних даних генеруємо структуру нейро-нечіткої мережі (рис. 4). Створена мережа в цілому має три входи та один вихід, а іï внутрішня структура складається 3 п'яти основних шарів, що й реалізують механізми логічних причинно-наслідкових зв'язків.

Наступним кроком до отримання дієздатної мережі $є$ проведення навчання(налаштування) нейро-нечіткої мережі (НHМ) на основі методу зворотного поширення помилки. Для цього необхідно задати певну кількість циклів навчання. Після їх проведення отримаємо мережу 3 перерахованими параметрами функцій належності. Процедура перерахунку триває, поки нев’язка перевищує заздалегідь установлене значення (рис. 5). Для настроювання функцій належності, крім методу зворотного поширення помилки, можуть використовуватися й інші алгоритми оптимізації, наприклад, метод Левенберга-Марквардта.

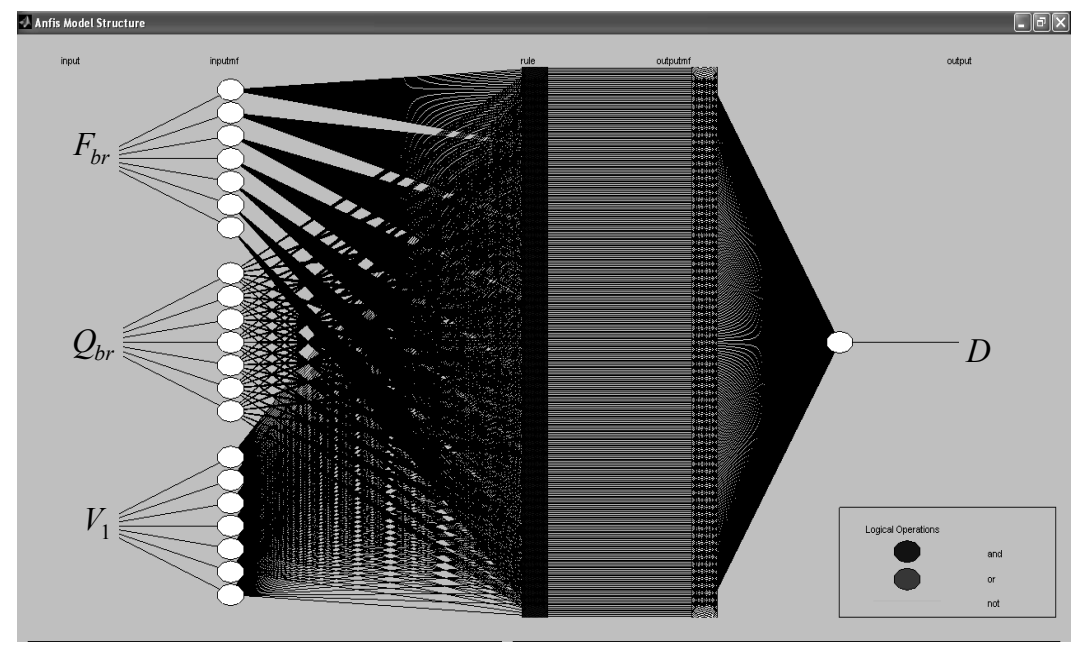

Рис. 4. Структура нейро-нечіткої мережі

Досліджуючи основну динаміку зміни похибки мережі, можна побачити (рис. 5) iі зміну у бік зменшення, що характеризує ефективний метод навчання та, відповідно, доцільність застосування такого підходу. 


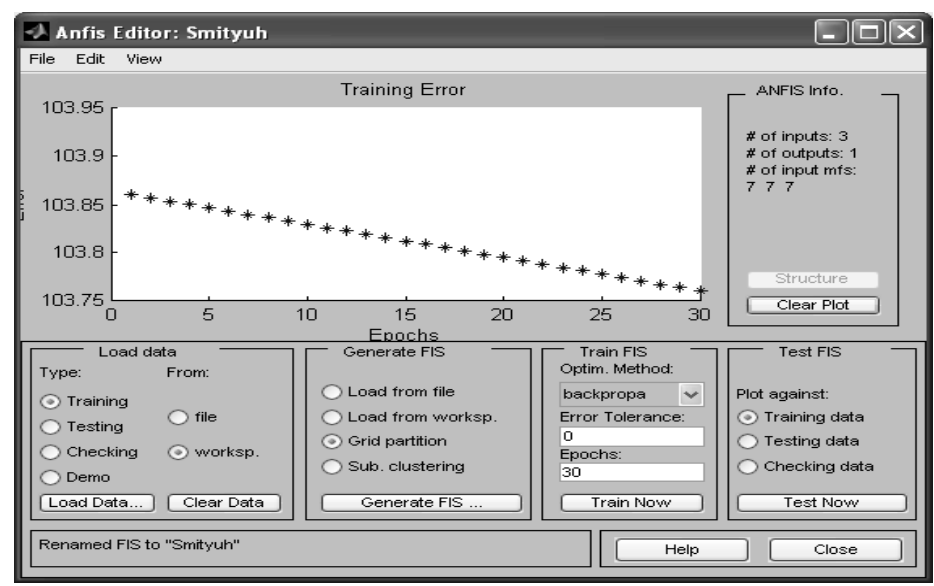

Рис. 5. Зміна похибки навчання мережі, що підтверджус приведення її до адекватності реальному об'скту

Після проведених навчань, ННМ отримаємо графічну інтерпретацію відгуку бази знань, що характеризує залежність вихідної змінної від множини вхідних змінних.

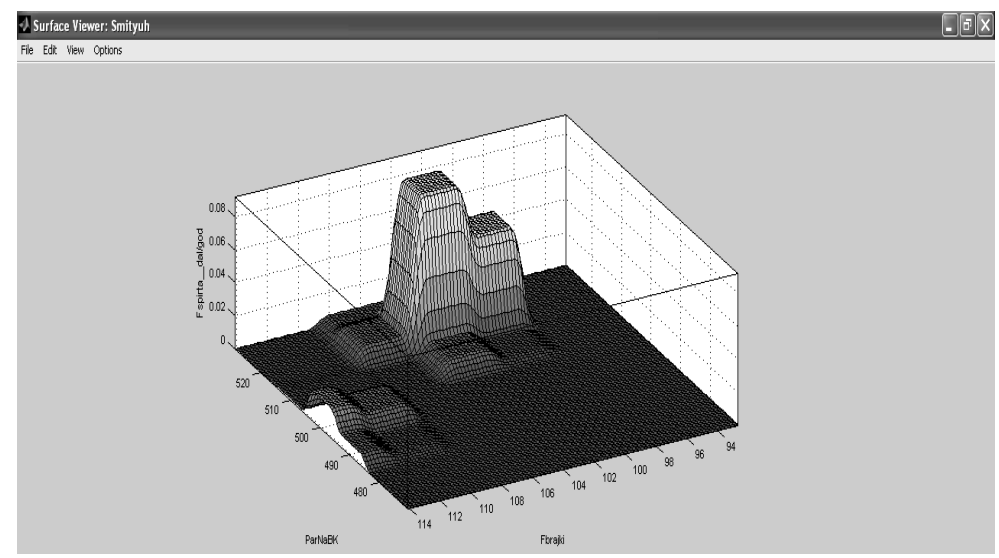

Рис. 6. Залежність витрати спирту з РК від витрати пари на БК і витрати бражки

Створена нечітка база знань показує всю множину нечітких залежностей $\mathrm{i}$ логіку кожного правила. Виходячи 3 отриманого результату, можна стверджувати, що зони екстремумів відповідають найкращим показникам продуктивності - витрати спирту при певних діапазонах витрати пари та витрати бражки на бражну колону, що може слугувати основою для підтримки прийняття рішень оператора технолога в різних виробничих ситуаціях.

Таким чином, вирішення задач ідентифікації на основі нейро-нечіткого підходу показало можливість встановлення причинно-наслідкових зв'язків між вхідними та вихідними змінними процесів брагоректифікації у вигляді нечітких правил. Розглянутий вище підхід дає змогу спростити роботу експертів при виявленні основних залежностей між вхідними та вихідними 
змінними, оскільки, маючи лише експериментальну статистику роботи окремих колон БРУ, можна на основі отриманої бази знань досліджувати основні характеристики процесів брагоректифікації. Такий підхід може бути використаний для вирішення задач ідентифікації широкого класу складних ОУ та створення баз знань.

\section{3. Комплексування ситуаційного керування та методів координації}

Розглянемо комплексування ситуаційного керування та методів координації. Як об'єкт розглядається технологічний комплекс (ТК) цукрового заводу, який складається зі значної кількості функціонально необхідних ступенів переробки сировини та напівпродуктів і відноситься до складних систем, оскільки він має такі характерні ознаки: [6]: складність, спостережність, керованість, чутливість, стійкість, координованість, адаптивність, ефективність, надійність, матеріаломісткість, живучість, металомісткість, енергоємність, капіталомісткість, трудомісткість, які необхідно забезпечувати і підтримувати на належному рівні.

3 одного боку, у ході виробництва цукру виникають труднощі при ідентифікації аварійних ситуацій, пов'язані зі складністю об'єкта управління (ОУ) та умов його функціонування. При цьому рішення оператора повинні прийматися оперативно, в реальному режимі часу, тому що затримка при реалізації керуючих впливів призводить до відчутних економічних втрат. Вирішення цієї проблеми для цукрових виробництв можливе на основі ситуаційного управління, яке, на відміну від класичної теорії, дає змогу здійснювати побудову логіко-лінгвістичних моделей, що забезпечують високий ступінь адекватності опису аварійних ситуацій, які виникають на ОУ. Функціональна структура інтелектуальної системи ситуаційного управління здійснює генерацію керуючих рішень на основі переробки даних і знань, що характеризують функціонування організаційно-ситуаційного об' єкта, представлена кортежем:

$$
U=<K, M, D, C, S, L, E>
$$

де $K$ - база знань; $M$ - блок математичного моделювання; $D$ - база даних; $C$ - блок виведення управлінських рішень; $S$ - блок аналізу ситуацій; $L-$ лінгвістичний процесор; $E-$ блок пояснення. Модель циклу прийняття рішень $з$ управління в проблемних ситуаціях (ПС) - нештатних, критичних, аварійних - подається у вигляді просторової багатовимірної структури знань:

$$
S^{\prime}=\{S, M, A, E, D, X, G\},
$$

де $S^{\prime}$ - ситуація, яка виникла в результаті рішення; $S$ - початкова ПС; $M-$ множина моделей розвитку ПС; $A-$ множина альтернатив розвитку ПС; $E-$ множина критеріїв оцінки ефективності рішень; $D$ - множина рішень; $X$ множина станів об'єкта; $G$ - мета управління об'єктом.

3 іншого боку, навіть коли система працюе в штатному режимі, відбуваються суттєві втрати потенційного прибутку, тому що зазвичай не враховуються взаємні зв'язки між підсистемами, а при оцінці ефективності функціонування ТК саме взаємні зв'язки між підсистемами мають найбільш суттєве значення. Тобто не вирішується задача координації - пошук оптимальних значень технологічних змінних просто не відбувається. 
Для вирішення задачі координації необхідно провести аналіз досліджуваного об'єкта, виділити підсистеми, критерій оцінки ефективності, сформувати алгоритми координації та комплекс системи управління на основі виділених підсистем. Розв'язанням задачі координації є визначення взаємодії підсистем, при яких управління, оптимальні за критеріями ефективності кожної з підсистем, є також оптимальними за загальним критерієм для ТК у цілому [7].

ТК цукрового заводу розглядається як сукупність підсистем дифузійного відділення, відділення очистки та випарного відділення, оскільки саме ці підсистеми мають нелінійні залежності. Наприклад, зі збільшенням відкачки дифузійного соку зменшується втрата цукру в жомі, що є покращенням ефективності функціонування ТК, проте зростають витрати на випарній установці, що, у свою чергу, зменшує ефективність.

Моделі дифузійного та випарного відділень описуються в Simulink у вигляді систем диференціальних рівнянь. Модель відділення очистки вважається квазістаціонарною. Саме в цій моделі враховуються зміни матеріальних потоків. Загальна оцінка ефективності функціонування технологічного комплексу iз системою управління виконується на основі узагальненого економічного показника - прибутку.

Детально структуру системи управління, яка була прийнята для досліджуваного об'єкта, відображено на рис. 7. На нижньому рівні виділені підсистеми (які мають найбільш складні нелінійні зв'язки), необхідні для управління кожної підсистеми ПЛК та ПК із SCADA. На верхньому рівні виділено структуру розробленої системи управління, яка, у свою чергу, складається 3 бази даних, куди записуються необхідні дані з кожної підсистеми та прийняті розробленою системою управлінські рішення, блоків координації та СППР. Блок координації з допомогою відомих математичних моделей за принципом прогнозування знаходить оптимальне рішення для збільшення ефективності функціонування ТК завдяки пошуку таких значень змінних, при яких прибуток ТК буде максимальним. Вирішення задачі координації має сприяти зменшенню ймовірності відхилень значень технологічних змінних за межі допустимих діапазонів. Блок СППР складається 3 двох складових.

Блок «дифузійне відділення» приймає рішення, використовуючи методи нечіткої логіки: за допомогою «блоку фазифікації» значення необхідних технологічних змінних перетворюються в нечіткі значення; при спрацюванні відомих правил 3 «бази правил» приймається відповідні рішення, після чого відбувається агрегація по кожній технологічній змінній; 3 допомогою «блоку дефазифікації» прийнятті рішення перетворюються у чітку форму і виводяться у зрозумілому для оператора вигляді. Правила для блоку «дифузійне відділення» формуються у форматі «якщо ..., то ...».

Блок «випарне відділення» за допомогою порівняння поточної ситуації 3 ситуаціями в «базі ситуацій» виводить інформацію оператору в разі виникнення нештатної ситуації в базі.

У випадку автоматичного режиму роботи прийняті рішення 3 «блоку координації» та «дифузійного відділення» записуються до бази даних. 


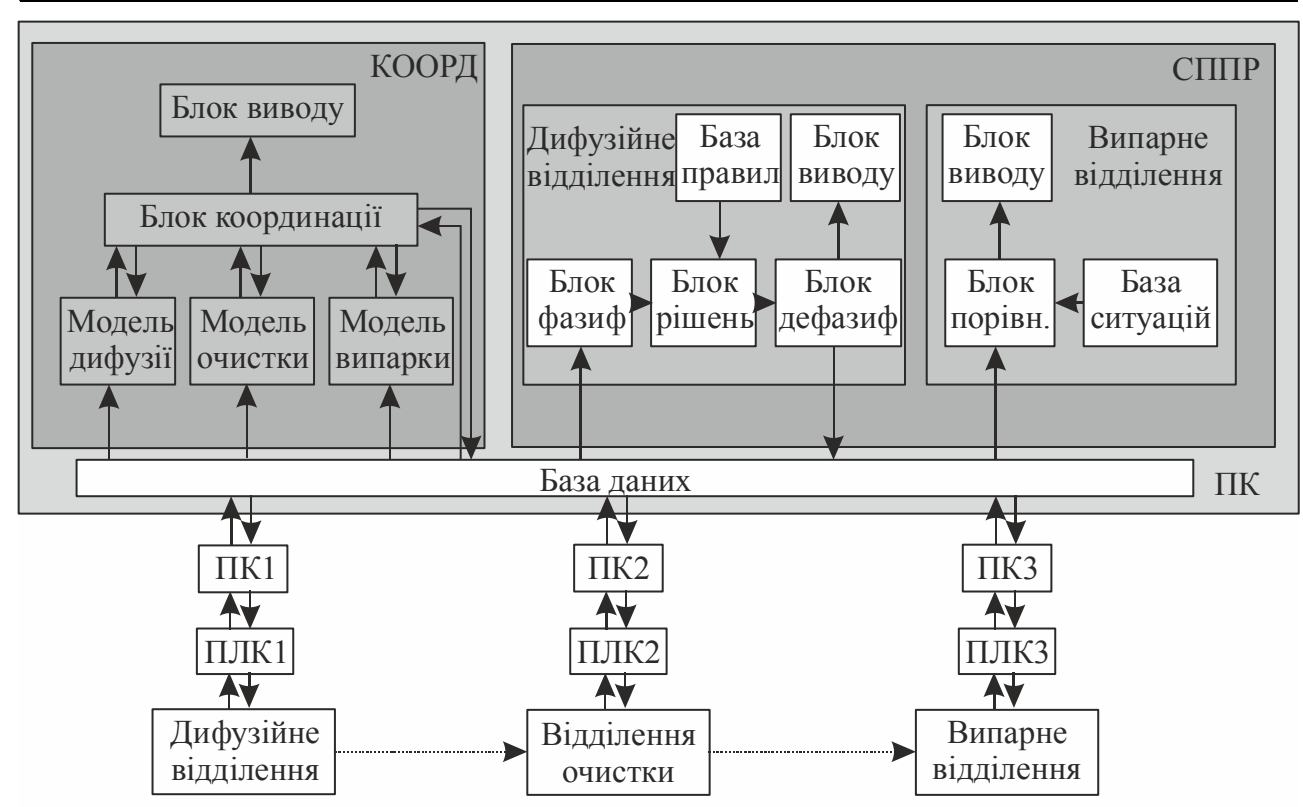

Рис. 7. Структура системи керування

Програмне забезпечення розроблено в середовищі MATLAB (рис. 8) і складається 3 двох систем: системи розв'язку задачі координації та системи підтримки прийняття рішень (СППР) для дифузійного й випарного відділень.

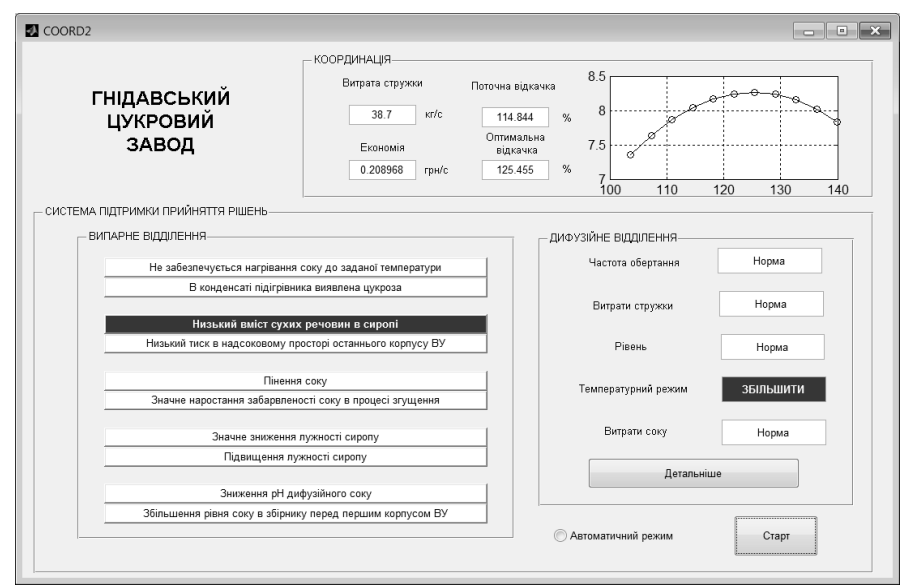

Рис. 8. Головне вікно розробленого програмного забезпечення

Програма зчитує всі необхідні поточні дані з файлу ехcel, куди вони записуються автоматично за допомогою встановленої на заводі SCADA програми. Система може працювати в автоматичному та порадчому режимі.

У разі вибору «Автоматичний режим» прийняті системою рішення автоматично записуються до бази даних і через SCADA передаються на ПЛК та на виконавчі механізми. 
Програма відображає поточне та рекомендоване значення відкачки, а також економію у разі зміни поточного значення на рекомендоване.

Програма відображає червоним кольором нештатні ситуації, які виникли, та поради (при натисканні на відповідну ситуацію) щодо їх усунення для СППР випарного відділення, а також поради у нечіткій та чіткій формі (при натисканні «Детальніше») для СППР дифузійного відділення.

Отже, програмне забезпечення запропонованої системи координації підсистем технологічного комплексу цукрового заводу на основі ситуаційного управління може бути інтегроване до вже існуючих АСУТП та дає змогу оперативно ідентифікувати виробничі ситуації; отримати оцінку поточного стану й ефективності ТК; оператору приймати рішення на основі рекомендацій, запропонованих системою; підвищити ефективність функціонування ТК за рахунок розв'язання задачі координації.

4. Комплексування аналітичних і синергетичних методів синтезу систем керування

Синергетику можна розглядати як сучасний етап розвитку ідей кібернетики та системних досліджень. Кібернетика та різноманітні напрямки загальної теорії систем вивчають процеси підтримання рівноваги (гомеостазу) у системах за рахунок зворотних зв'язків, а також процеси керування системами. Кібернетика намагається звести й описати нелінійні процеси еволюції систем за допомогою лінійних моделей (принаймні на окремих етапах, коли існує така можливість). Синергетика, базуючись виключно на нелінійних моделях, забезпечує ресурсоощадне керування на основі явищ самоорганізації в складних об'єктах.

У рамках синергетичного керування для технологічних комплексів раціонально використати метод аналітичного конструювання агрегованих регуляторів (АКАР), який дає змогу забезпечити оптимальний міжатрактивний перехід в об'єкті шляхом реалізації аналітично розрахованих слабкопотужних керувальних дій резонансного характеру.

Завдання синергетичного керування методом АКАР розглянемо на прикладі технологічного процессу попередньої дефекації.

Математична модель процессу попередньої дефекації має вигляд:

$$
\begin{aligned}
& \frac{d C_{\mathrm{CaO} \_ \text {Бм }}}{d \tau}=\frac{F_{\mathrm{CaO} \_ \text {Бм }} \cdot C_{\mathrm{CaO}}^{\mathrm{Bx} .}}{V}-k_{1} \cdot C_{\mathrm{CaO}} \cdot C_{\text {c.p. }}-\frac{F_{\text {д.с. }}+F_{\text {зв. }}}{V} \cdot C_{\mathrm{CaO}}, \\
& \frac{d C_{\text {c.p. }}}{d \tau}=\frac{F_{\text {д.с. }} \cdot C_{\text {c.p. }}^{\text {вх. }}+F_{\text {зв. }} \cdot C_{\text {c.p. }}^{\text {3в. }}}{V}-k_{2} \cdot C_{\text {c.p. }} \cdot C_{\mathrm{CaO}}-\frac{F_{\text {д.с. }}+F_{\text {зв. }}+F_{\text {CаO_БМ }}}{V} \cdot C_{\text {c.p. }} \text {, } \\
& \frac{d T_{\text {д.с. }}}{d \tau}=\frac{F_{\mathrm{CaO} \_ \text {БМ }} \cdot T_{\mathrm{CaO}}^{\mathrm{Bx}}+F_{\text {д.с. }} \cdot T_{\text {д.с. }}^{\text {вх. }}+F_{\text {зв. }} \cdot T_{\text {зв. }}}{V}+ \\
& +\left[k_{1} \cdot F_{\text {СаO_БМ }}-k_{2}\left(F_{\text {д.с. }}+F_{\text {зв. }}\right)\right] \cdot Q-\frac{k_{\mathrm{T}} \cdot F}{\rho \cdot C_{\mathrm{p}} \cdot V} \cdot\left(T_{\text {д.с. }}^{\mathrm{Bx}}-T_{\mathrm{p.}}\right)- \\
& -\frac{F_{\mathrm{CaO}}+F_{\text {д.с. }}+F_{\text {зв. }}}{V} \cdot T_{\text {д.с. }}+\frac{T_{\text {д.с. }}^{\text {вх. }}-T_{\text {д.с. }}}{V} \cdot F_{\text {CaO_БМ }},
\end{aligned}
$$




$$
\frac{d T_{\mathrm{p}}}{d \tau}=\frac{\left(T_{\text {пари }}-T_{\mathrm{p} .}\right) \cdot F_{\text {пари }}}{V_{\mathrm{p} .}}-\frac{k_{\mathrm{T}} \cdot F}{\rho_{\text {пари }} \cdot C_{\text {р.пари }} \cdot V_{\mathrm{p} .}} \cdot\left(T_{\mathrm{p} .}-T_{\text {д.с. }}\right),
$$

де $F_{\text {Сао_ьм }}$ - витрата вапнякового молока, м ${ }^{3} /$ год.; $F_{\text {д.с. }}$ - витрата дифузійного соку, $\mathrm{m}^{3} /$ год.; $F_{\text {зв. }}$ - витрата соку повернення, $\mathrm{m}^{3} /$ год.; $T_{\text {д.с. }}-$ температура дифузійного соку, ${ }^{\circ} \mathrm{C} ; T_{\text {д.с. }}^{\text {вx. }}$ - температура дифузійного соку на вході, ${ }^{\circ} \mathrm{C} ; T_{\mathrm{CaO}}^{\mathrm{Bx} .}-$ температура вапняного молока на вході, ${ }^{\circ} \mathrm{C} ; T_{\text {зв. }}$ - температура соку повернення, ${ }^{\circ} \mathrm{C} ; T_{\mathrm{p} .}$ - температура в паровій рубашці, ${ }^{\circ} \mathrm{C} ; C_{\mathrm{CaO}}-$ концентрація вапняного молока, \%; $C_{\text {c.p. }}^{\text {в. }}$ - концентрація сухих речовин в дифузійному соку на вході, \%; $C_{\text {c.p. }}$ - концентрація сухих речовин у дифузійному соку, \%; $C_{\text {c.p. }}^{3 \text {. }}$ - концентрація сухих речовин соку повернення, $\% ; C_{\mathrm{CaO}}^{\mathrm{Bx} .}-$ концентрація вапняного молока на вході, \%; $C_{\text {р.пари }}-$ теплоємність пари в рубашці, кал/г; $k_{\mathrm{T}}$ - коефіцієнт теплопередачі; $F$ - поверхня теплопередачі, $\mathrm{M}^{2} ; \quad k_{i}=k_{i 0} \cdot e^{-\left(E_{i} /\left(R \cdot\left(T_{\text {д... }}+273,15\right)\right)\right)} \quad$ - константи швидкості реакцій; $k_{i 0}-$ передекспоненціальний коефіцієнт; $E_{i}-$ енергія активації реакцій; $R-$ універсальна газова стала; $Q=\Delta H /\left(\rho \cdot C_{\mathrm{p}}\right), \Delta H-$ тепловий ефект реакції (віднесений до швидкості по компоненті вапняного молока); $C_{\mathrm{p}}-$ теплоємність речовин в апараті та вихідних потоках, кал/г; $V_{\text {p. }}-$ об'єм парової рубашки теплообмінника, м³ $V$ - об'єм переддефекатора, м³ $\rho_{\text {пари }}$ - гус-

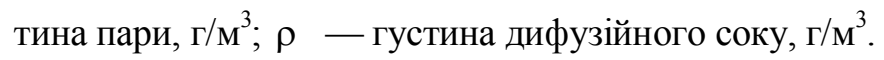

Проаналізувавши рівняння (8), можна зробити висновок, що система нелінійна та взаємозв'язана. Виходячи з цього, для розв'язання задачі оптимального керування застосуємо методологію синергетичного керування, а саме: метод аналітичного конструювання агрегованих регуляторів (АКАР).

Згідно 3 методом АКАР необхідно синтезувати закони керування $u_{1}\left(C_{\text {Сао_ьм }}, C_{\text {c.p. }}, T_{\text {д.с. }}\right)$, та $u_{2}\left(C_{\text {СаО_Бм }}, T_{\text {д.с. }}, T_{\text {p. }}\right)$, які забезпечують, при стабілізації температури дефекованого соку, $T_{\text {д.с. }}$, оптимальне значення величини $\mathrm{pH}, \mathrm{pH}_{\text {Бм }}$, дефекованого соку, тобто $T_{\text {д.с. }}=T_{\text {д.c. }}^{0}, C_{\text {c.p. }}=C_{\text {c.p. }}^{0}$. Як $u_{1}$ вибираємо витрату вапняного молока $F_{\text {Сао_ьм }}, u_{2}$ - витрата пари $F_{\text {пари }}$.

Враховуючи те, що система має два керувальних впливи, застосуємо паралельно-послідовну процедуру розгляду інваріантних багатообразів:

$$
\psi_{1}\left(C_{\text {CaO_Бм }}, C_{\text {c.p. }}, T_{\text {д.с. }}\right)=0, \psi_{2}\left(C_{\text {CaO_Бм }}, T_{\text {д.с. }}, T_{\text {p. }}\right)=0
$$

Паралельно введені багатообрази відіграють роль атракторів притягнення зображаючої точки замкненої системи при синтезованому законі керування $u_{1}\left(C_{\text {СаO_Бм }}, C_{\text {c.p. }}, T_{\text {д.с. }}\right)$, та $u_{2}\left(C_{\text {СаO_Бм }}, T_{\text {д.с. }}, T_{\text {p. }}\right)$. При цьому зображаюча точка переміщується у фазовому просторі на перетин багатообразів $\psi_{1}=0, \psi_{2}=0$. 
Керування $u_{1}$ входить в керування $u_{2}$ підсистеми і безпосередньо впливає на величину рН дефекованого соку. Виходячи 3 цього, задаємо макрозмінну $\psi_{1} \mathrm{y}$ вигляді $\psi_{1}=C_{\text {c.p. }}-C_{\text {c.p. }}^{0}$. Оскільки витрата пари $u_{2}$ безпосередньо не впливає на температуру $T_{\text {д.с. }}$, то необхідно сконструювати функцію $\psi_{2}\left(C_{\text {Сао_Бм }}, T_{\text {д.с. }}\right.$, $\left.T_{\text {p. }}\right)=0$, яка зв'язувала $6 T_{\text {д.с. }}$ ' фазовими координатами $C_{\text {Сао_Бм }}$ i $T_{\text {p. }}$.

Сконструюємо функцію зв'язку макрозмінних $C_{\text {Сао_ьм }}$ та $T_{\text {д.с. }}$ :

$$
\psi_{2}=T_{\text {p. }}+v\left(C_{\text {СаО_Бм }}, T_{\text {д.с. }}\right),
$$

де $v\left(C_{\text {СаО_ьм }}, T_{\text {д.с. }}\right)$ - функція залежності величини $\mathrm{pH}$ від температури в дефекаторі.

У випадку синтезу законів керування $u_{1}\left(C_{\text {Сао_ьм }}, C_{\text {c.p. }}, T_{\text {д.с. }}\right)$ та $u_{2}\left(C_{\text {Сао_ьм }}\right.$, $\left.T_{\text {д.с. }}, T_{\text {p. }}\right)$, які переводять точку зображення в околицю перетину багатообразів:

$$
C_{\text {c.p. }}-C_{\text {c.p. }}^{0}=0, T_{\text {p. }}+v\left(C_{\text {CaO_Бм }},\left(T_{\text {д.c. }}^{\text {Bx. }}-T_{\text {д.с. }}\right)\right)=0 .
$$

Зміна макрозмінних $\psi_{1}$ та $\psi_{2}$ підпорядковуються виразу (9):

$$
T_{i} \cdot \psi_{i}(\tau)+\psi_{i}(\tau)=0
$$

3 урахуванням (10) рівняння (11) набуде вигляду:

$$
\begin{gathered}
T_{1} \cdot \frac{d C_{\text {c.p. }}}{d \tau}+\left(C_{\text {c.p. }}-C_{\text {c.p. }}^{0}\right)=0, \\
T_{2} \cdot\left[\frac{d T_{\text {p. }}}{d \tau}+\frac{\partial v}{\partial C_{\text {СаО_Бм }}} \cdot \frac{d C_{\text {СаО_БМ }}}{d \tau}+\frac{\partial v}{\partial T_{\text {д.с. }}} \cdot \frac{d T_{\text {д.с. }}}{d \tau}\right]+ \\
+T_{\text {p. }}+v\left(C_{\text {СаО_Бм }},\left(T_{\text {д.с. }}^{\text {вх. }}-T_{\text {д.с. }}\right)\right)=0 .
\end{gathered}
$$

На основі рівняння моделі (8) і з урахуванням (12) сформулюємо закони взаємозв'язаного керування технологічним процесом дефекації:

$$
\begin{aligned}
& u_{1}=\frac{\left(F_{\text {д.c. }} \cdot C_{\text {c.p. }}^{\text {BX. }}+F_{\text {3в. }} \cdot C_{\text {c.p. }}^{\text {3в. }}-k_{2}\right) \cdot C_{\text {c.pp }} \cdot V-\left(F_{\text {д.c. }}+F_{3 \text { в. }}+F_{\text {CaO_БM }}\right) \cdot C_{\text {c.p. }}}{C_{\text {c.p. }}}+ \\
& +\frac{V \cdot\left(C_{\text {c.p. }}-C_{\text {c.p. }}^{0}\right)}{C_{\text {c.p. }} \cdot T_{1}}, u_{2}=\frac{\left(T_{\text {p. }}+v\right) \cdot V_{\text {p. }}}{\left(T_{\text {пари }}-T_{\text {p. }}\right) \cdot T_{2}}- \\
& -\frac{\frac{k_{\mathrm{T}} \cdot F}{\rho_{\text {пари }} \cdot C_{\text {р.пари }} \cdot V_{\mathrm{p} .}} \cdot\left(T_{\mathrm{p} .}-T_{\text {д.с. }}^{\mathrm{Bx}}\right)}{T_{\text {пари }}-T_{\text {p. }}}-\frac{\partial v}{\partial C_{\text {СаО_БМ }}} \times \\
& \times \frac{\left(\frac{F_{\mathrm{CaO} \_ \text {БМ }} \cdot C_{\mathrm{CaO}}^{\mathrm{Bx}}}{V}-k_{1} \cdot C_{\mathrm{CaO}}-\frac{F_{\text {д.с. }}+F_{\text {зв. }}}{V} \cdot C_{\mathrm{CаO}}\right) \cdot F_{\mathrm{CaO} \_ \text {Бм }} \cdot C_{\mathrm{CaO} \_ \text {БМ }}}{T_{\text {пари }}-T_{\mathrm{p} .}}-
\end{aligned}
$$




$$
\begin{aligned}
& -\frac{\partial v}{\partial T_{\text {д.с. }}} \cdot\left(\frac{F_{\mathrm{CaO} \_ \text {БM }} \cdot T_{\mathrm{CaO}}^{\text {Bх. }}+F_{\text {д.с. }} \cdot T_{\text {д.с. }}^{\text {вх. }}+F_{\text {зв. }} \cdot T_{\text {зв. }}}{V}+\right. \\
& +\left[k_{1} \cdot F_{\text {СаО_Бм }}-k_{2}\left(F_{\text {д.с. }}+F_{\text {3в. }}\right)\right] \times \\
& \times Q-\frac{k_{\mathrm{T}} \cdot F}{\rho \cdot C_{\mathrm{p}} \cdot V} \cdot T_{\text {д.с. }}-\frac{F_{\mathrm{CaO} \_ \text {БM }}+F_{\text {д.с. }}+F_{\text {3в. }}}{V} \cdot T_{\text {д.с. }}+\frac{T_{\text {д.с. }}-T_{\mathrm{CaO}}^{\mathrm{Bx}}}{V} \times \\
& \left.\times F_{\text {СаО_Бм }}+T_{\text {p. }}+T_{\text {д.с. }} \cdot F_{\text {СаО_Бм }}\right) \cdot V_{\text {р. }} / T_{\text {пари }}-T_{\text {р. }}
\end{aligned}
$$

Використовуючи отримані співвідношення, можна синтезувати керувальні впливи для технологічних операцій I та II сатурації, а також для проміжної дефекації.

Параметри налаштування законів керування регламентують час регулювання $T_{1}, T_{2 . .}$ Умовою стійкості системи є такі значення: $T_{1}>0, T_{2}>0$.

На рис. 9 представлено результати моделювання динамічної системи із синтезованими регуляторами. При моделюванні використовувались усереднені технологічні показники параметрів процесу дефекації на обладнанні 3 продуктивністю 3000 т/добу. Якість керування оцінювалася за інтегральним квадратичним критерієм.

Таким чином у результаті проведених досліджень було виявлено, що система стійка до збурень, а час регулювання залежить лише від величин $T_{1}, T_{2}$. Синтезована синергетична система керування довела свою працездатність, стійкість та ефективність.

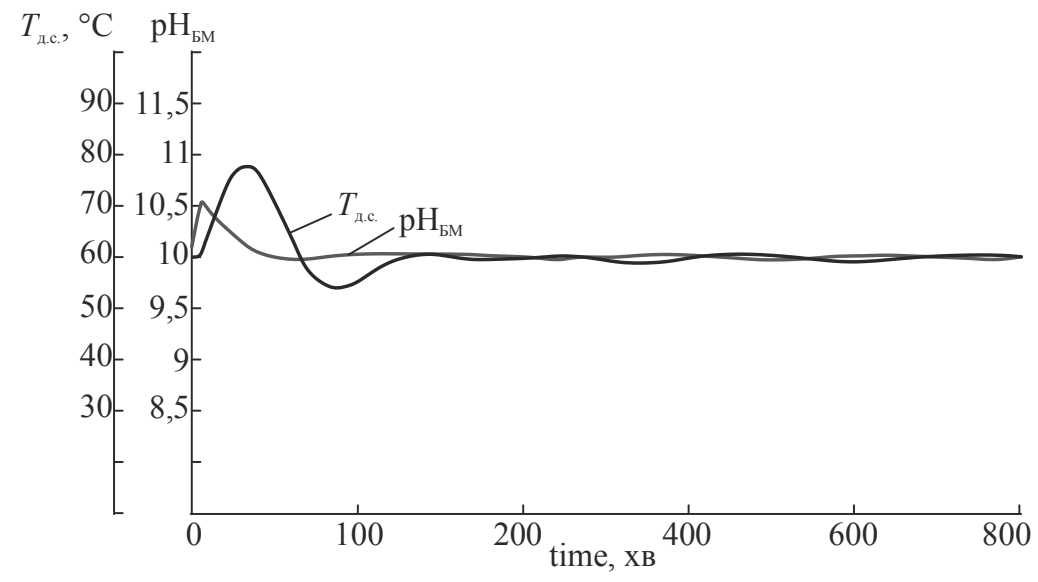

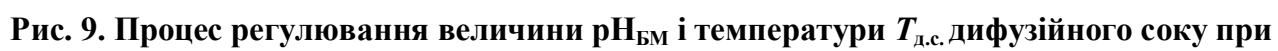
взаємозв'язаному керуванні за умови $T_{1}=T_{2}=12$

\section{Висновки}

Приклади моделювання систем керування технологічними об'єктами, що поєднують сучасні методи теорії керування, довели свою працездатність. Ускладнення системи та введення нових алгоритмів у структуру керування технологічним об'єктом дає перевагу в значному покращенні якісних властивостей системи та забезпечує іiі автономну роботу на значно більшому проміжку часу експлуатації системи. 
Наступним етапом теоретичного та практичного обгрунтування доцільності використання комплексування методів теорії керування є розробка умов застосування різних методів з урахуванням визначальних властивостей об'єкта та побудова класифікаційних ознак приналежності системи до відповідного класу методів керування.

\section{Література}

1. Ладанюк А.П. Комплексування методів теорії керування в системах автоматизації технологічних об'єктів. Частина 1 / А.П. Ладанюк, Н.М. Луцька, В.Д. Кишенько, Я.В. Смітюх, Д.А. Шумигай // Наукові праці Національного університету харчових технологій. Київ : НУХТ. - 2017.- № 4. - С. 8-16.

2. Leva A., Cox C., Ruano A. Hands-on PID autotuning: a guide to better utilization. IFAC Professional Brief. - http://www.ifac-control.org.

3. Apkarian P. and Noll D. "Nonsmooth H-infinity Synthesis" IEEE Transactions on Automatic Control. — Vol. 51. — Number 1 _- 2006. - P. 71-86.

4. Ротштейн А.П. Интеллектуальные технологии идентификации: нечеткая логика, генетические алгоритмы, нейронные сети. — Винница : Универсум-Винница, 1999. — $320 \mathrm{c}$.

5. Jang J.-S.R. ANFIS: Adaptive-Network-Based Fuzzy Inference System // IEEE Trans. Systems \& Cybernetics. — 1993. - Vol. 23. - P. 665-685.

6. Месарович М. Теория иерархических многоуровневых систем / М. Месарович, Л. Мако, И. Такахара. - Москва : Мир, 1973. - 344 с.

7. Ladanyuk A. Situational Coordination of Continuous Technological Complexes Subsystems / A. Ladanyuk, D. Shumygai, R. Boiko // Journal of Automation and Information Sciences USA. — Beggelhouse. - 2013. - Vol. 45. - P. 68-74. 